\title{
Towards Effective Mitigation of the Digital Transformation and COVID-19 Risk on the Unemployment in Mobile Operators in Egypt
}

\author{
Ashraf Elsafty $^{1} \&$ Ahmed Elzeftawy $^{1}$ \\ ${ }^{1}$ Adjunct Assistant Professor, Maastricht School of Management, Cairo Outreach, Egypt \\ ${ }^{1}$ DBA Candidate, University of Business and International Studies, UBIS, Brilliance-Cairo Outreach, Egypt \\ Correspondence: Ashraf Elsafty, Adjunct Assistant Professor, Maastricht School of Management, Cairo Outreach, \\ Egypt. ORCID ID: https://orcid.org/0000-0002-9377-7286. E-mail: ashraf@ashrafelsafty.com
}

Received: December 7, 2021

Accepted: January 2, 2022

Online Published: January 21, 2022

doi:10.5539/ijbm.v17n2p123

URL: https://doi.org/10.5539/ijbm.v17n2p123

\begin{abstract}
The new era of Digital transformation will Destroy many tasks and will create new owns, only certain tasks will depend on human skills which was defined by Carl Benedikt Frey and Michael A. Osborne, 2013 in which they called it, the "Engineering-Bottlenecks. Other tasks also defined by Katharina Dengler, Britta Matthes and Wiebke Paulus, 2014 in which they use the assignment of activities explained by Alexandra Spitz-Oener for non-automatable tasks and categorize them as: analytical non-routine tasks, interactive non-routine tasks. To mitigate the Risk of Automation and AI, there is a need for Upskilling and Reskilling the current workforce to perform the un-automatable tasks, created from the development of new products and services as well as performing new complementary tasks created to support the new automated systems.

The purpose of this paper is to examine whether the current Reskilling and Upskilling activities are organized in the right track to fill in the new created jobs, and whether they are making use of COVID-19, which gave a surplus of time by WFH and cutting the transportation time.

The conclusion of this research is $38 \%$ of the existing tasks, is under the risk of automation and $51 \%$ of the employees more than $40 \%$ of their current tasks are subject to automation. COVID-19 through WFH can provide more time for learning and development. Reskilling and Upskilling of the current workforce will not be effective unless it is correlated with the new created jobs from introducing new products and services or complementary jobs for newly introduced automated systems as the new created jobs are mainly SW developers.
\end{abstract}

The quantitative method used in this research is based on survey through questionnaires to a probability sample for 100 Engineers working in a technical department in Mobile Operator, and the Qualitative method is based on Structured interviews with a non-probability sample of Technology Managers, as Judgmental Sampling.

Keywords: Unemployment, Automation, Artificial Intelligent, Digital Transformation, COVID-19, Upskilling, Reskilling, Complementary jobs, Digital products, Digital Services.

\section{Introduction}

$41 \%$ of the Technology staff in the Mobile operators will be on Risk of unemployment because of the Digital Transformation. COVID-19 will add another 8\% Risk (Elsafty \& Elzeftawy, 2021). Upskilling, and Reskilling for the current workforce are required to mitigate the effect of this technological unemployment and to create new opportunities. Reskilling for existing workers to do other jobs which will not be automated and Upskilling for others to do more complex jobs (Forum, 2018). The research used the Nine elements model/framework by Elsafty $(2018,2019,2020,2021)$ to analyze the context and has been used in several research papers (Elsafty, Elsayed, \& Shaaban, 2020; Elsafty \& AlNawaly, 2020; Elsafty \& Ragheb, 2020/2021; Elsafty \& Abadir \& Sharawy, 2020; Elsafty, A., Elbouseery, I., \& Shaarawy, A., 2020; Elsafty, A., \& Elzeftawy, A., 2021; Elsafty, A., \& Elshahed, M., 2021; Elsafty, A., \& Osman, M., 2021). While COVID-19 and working from home will save transportation time which will increase the opportunity for training through online training which was not so preferred before the pandemic (Fitzpatrick, Gill, Ari Libarikian, Smaje, \& Zemmel, 2020). The wide spread of technology and automation will change employment. Many people occupying traditional jobs will need reskilling and others in less systematic jobs will need upskilling.

From the Employers perspective, Reskilling and Upskilling for the people is a matter for Business case to choose 
what is financially attractive, but from the government perspective, there is a different quantifiable 'business case'. Preventing unemployment through reskilling and upskilling will maintain the government tax income, avoid the government from paying compensation and insurance as well as a range of costs that are harder to quantify, such as the effect of job displacement on the families of those displaced (Pablo Illanes, Susan Lund, Mona Mourshed, Scott Rutherford, and Magnus Tyreman, 2018). In the previous industrial revolutions, the introduction for a New Machines created new class of engineers, machinists, repairmen, conductors, back-office workers, and managers who involved in the introduction and the operation of these new technologies. The introduction of industrial robots, digital technologies and computer-controlled machines are again witnessing the emergence of new tasks like programming, data administrators, analysts, and computer support specialists. Automation allows firms to substitute capital for tasks previously performed by labor, while the creation of new tasks which use and operate this technology is a must (Acemoglu \& Restrepo, 2017). Additional jobs were created during the introduction of new products and productivity gains from Automation. In many cases positives and negatives cancel each other (Kropp \& Dengler, 2019).

\subsection{Problem Definition}

The widespread of the digital transformation practices, mainly Automation \& AI which was accelerated by COVID-19, made several jobs on risk of automation not only routine tasks, but AI also enable the automation for more complicated tasks such as car driving. Workers will need to start Reskilling and Upskilling to be able to perform un-automatable tasks which depends on human skills, as it is difficult in the time being to be automated. Also, to be able to catch the opportunities of the newly job created by introducing new digital products and services, and the complementary jobs created to support the new automated systems. This can mitigate part of these risks and reduce the risk on unemployment.

\section{Literature Review}

Digital Transformation will destroy many jobs with a rate was not seen before. Other forces can mitigate this effect like Upskilling and Reskilling of the current workforce to perform the un-automatable tasks, which created by introducing new products and services, and complementary tasks created to support the new automated systems. Capitalize on these forces can protect from unemployment in the time being. Two important factors should be stated:

1-Upskilling is about learning new competencies to cope with the current evolving roles. 2- Reskilling is about learning new competencies to move from a Risky automatable job to a safer one.

The need to acquire new skills to remain employed was highlighted by many researchers without quantifying the success or failures of this direction. The effect of reskilling and upskilling on the current employment are illustrated in figure 1 .
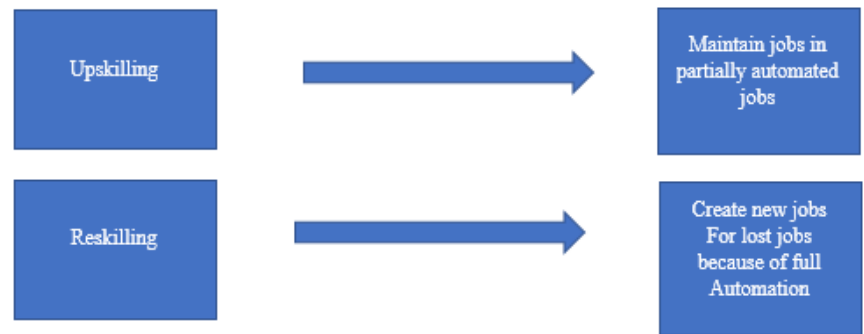

Figure 1. Reskilling \& Upskilling

New products and services arise after the adoption of new technology. The New products and services will create new tasks and jobs which was highlighted with examples by many researchers without quantifying the success or failures of this direction. New products and services will add new employees, part of them will be insiders from the organization through reskilling and outsiders will be newly hired as shown in figure 2 . 


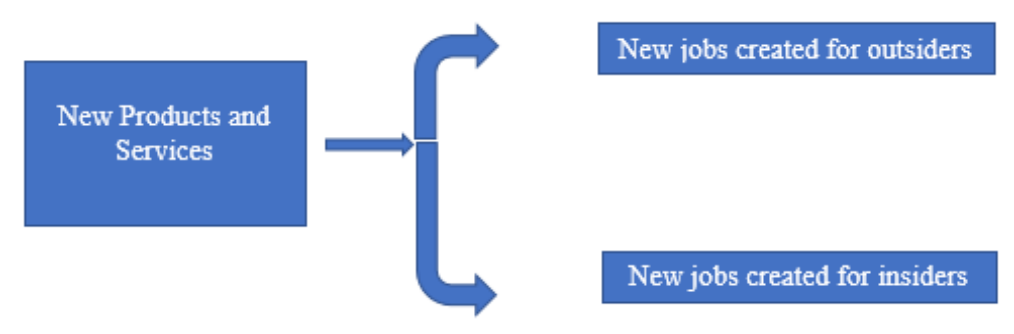

Figure 2. New Products and services

Complementary jobs are when new jobs arise to complement the new created Automated systems. Several researchers claim that the New digital product will create another supporting jobs. This argument was highlighted by many researchers without quantifying the success or failures of this direction. Complementary Jobs will create opportunities for insiders and outsiders of the organization to join the workforce as seen in figure 3.

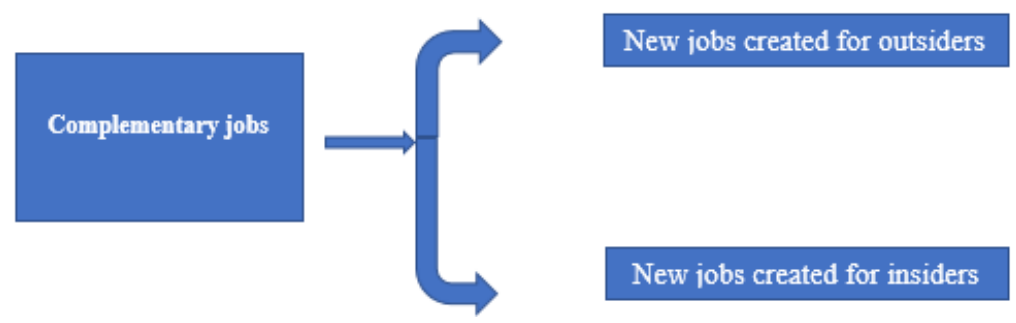

Figure 3. Complementary jobs

\subsection{Upskilling and Reskilling}

In the first four decades after World War II, there was a move from physical demanding jobs to skilled demanding jobs whether it is blue-collar or white collar one. Agriculture employment decline 4\% per decade, and the skilled jobs grew by 3\% per decade. After 1970 technical, managerial occupations grew, and skilled blue-collar occupations shrank rapidly. This is because computer take over routine tasks (Autor, 2015). Recently, not only low-skilled tasks are the one being automated but also any task which the machine can perform better than the human being (which is evolving) will displace those workers. The best way to get the best of new technologies is to modify the production processes in which using of high-skilled workers instead of low-skilled ones (Brynjolfsson \& Andrew, 2014). Digital transformation will change employment, the biggest challenges to employment will be from automation, in the form of robots and artificial intelligence. Several jobs will be obsolete, others will be reduced, and new jobs will be created. The previous researchers have no agreement on numbers, however the threat of losing jobs exists and a new opportunities are also existing. Both depend on the personal skills and the engagement in continuous training. Table 2 represent the top emerging and declining jobs in US according to the bureau of labor statistics (Forum, The Future of Jobs Report, 2018) . 
Table 1. Top emerging and declining jobs in US

\begin{tabular}{|c|c|c|c|}
\hline \multicolumn{2}{|c|}{ Top 10 emerging jobs } & \multicolumn{2}{|c|}{ Top 10 declining jobs } \\
\hline 1 & Big Data Architects & 1 & Team Assemblers \\
\hline 2 & Automation Technicians & 2 & $\begin{array}{l}\text { Secretaries and Administrative Assistants, except Legal, Medical and } \\
\text { Executive }\end{array}$ \\
\hline 3 & Renewable Energy Engineers & 3 & Inspectors, Testers, Sorters, Samplers and Weighers \\
\hline 4 & Automation Engineers & 4 & $\begin{array}{l}\text { Drilling and Boring Machine Tool Setters, Operators and Tenders, } \\
\text { Metal and Plastic }\end{array}$ \\
\hline 5 & $\begin{array}{l}\text { Organizational } \\
\text { Specialists }\end{array}$ & 5 & Electrical and Electronic Equipment Assemblers \\
\hline 6 & New Technology Specialists & 6 & $\begin{array}{l}\text { Milling and Planning Machine Setters, Operators and Tenders, Metal } \\
\text { and Plastic }\end{array}$ \\
\hline 7 & IT Administrators & 7 & Data Entry \\
\hline 8 & Digital Transformation Specialists & 8 & Paper Goods Machine Setters, Operators and Tenders \\
\hline 9 & IT Project Managers & 9 & Bookkeeping, Accounting and Auditing Clerks \\
\hline 10 & Data Analysts (General) & 10 & Cashiers \\
\hline
\end{tabular}

Source: The Future of Jobs Report. World Economic Forum, 2018 (Forum, The Future of Jobs Report, 2018).

whom will adopt to the new technology will be among the survivor's workers (Arntz, Gregory, \& Zierahn, 2019). The expectation that a growth of high-education/high-wage jobs at one end and low-education/low-wage jobs at the other end, leaving the middle-education/middle-wages category at risk. These phenomena are well known phenomena called job polarization (Autor, 2015). Some tasks/skills that constitute 'engineering bottlenecks' to automation, including problem-solving or social intelligence, caring, perception and situational, will remain un-automated for reasonable time (Pouliakas, 2018). There are two groups of tasks where robots cannot compete with humans, not even in the long term; activities that require creative intelligence (e.g., critical thinking, problem-solving, innovative reflection, creativity, intuition, and innovation) and activities that require social intelligence (e.g., cooperative skills, communication, human relationships, persuasion, agreement, assistance, and emotional support) (Csefalvay, 2019). Acquiring such skills protect workers jobs from being automated. Also, jobs that are intensive in manual tasks are neither subject to automation nor to substitution (Autor, 2015). Daron Acemoglu and David Autor Suggests that work can be divided into a two-by-two matrix cognitive vs manual and routine vs non-routine they found that the demand for work has been falling dramatically for routine tasks regardless of whether they are cognitive or manual. This should lead to job polarization and collapse in jobs depends on routine tasks (Brynjolfsson \& Andrew, 2014). Automation will not only affect tasks and jobs, but it will also affect the firm's structure by delayering of management hierarchy. Many of the middle managers will be displaced as many tasks previously under their management will disappear (Autor, 2015). Further Education and continuous training can increase the workers mobility to change their jobs from declining occupations to an expanding one (Arntz, Gregory, \& Zierahn, 2019). people have big data and Analytics skills will have higher values than others in which they have more human capital (Brynjolfsson \& Andrew, 2014). When the demand on certain occupations in certain industries fall, the wages of this jobs will fall which will not give incentive to more automation, which in turn will limit the unemployment. At the same time, workers will try to leave these segments, which will increase the remaining labors wages. The supply responses may thus reduce the automation effect. Continuous training and education are a prime recommendation to raise mobility. Accelerated mobility from shrinking segments to growing segments will increase the opportunities for jobs gain with high wage (Arntz, Gregory, \& Zierahn, 2019). Higher Education level will increase human abilities to be ahead of the machines. The new business models will involve continuous change which will raise the importance of continuing education to mitigate the risk of the growing technological advances. Investment in the training consider a high cost for workers and firms. Firms must recognize the importance of the training for its advance and for not to have to lay off than searching for new hires frequently. Workers will have to recognize that they will live in a continuous change in which they should adopt on and looking always for new opportunities and the skills level required to fill in this job (Doménech, García, Montañez, \& Neut, 2017). Continuous learning is mainly a personal responsibility for every employee to assess and take the necessary training or education on their own and not to depend on their employer to avoid losing their jobs and stay away from the labor market (Bonekamp \& Sure, 2015) .

Although Upskilling and Reskilling to be considered as a key issue in mitigating the effect of job automation. The employers should have the motivation to invest in whom their jobs are subject to automation. We can 
find-out that the private sector in EU is not providing the necessary training while investing in automation, in which will increase the risk of unemployment. Training in soft skills is also required to increase the jobs in non-technical field to mitigate the automation effect. One of the famous soft skills are the four C's (communication, collaboration, creativity, and critical thinking) is admittedly a critical parameter of the equation (Pouliakas, 2018). One solution, the firms to focus on displaced workers re-training and other educational enhancement initiatives such as part-time college programs. In Singapore Ministry of Manpower developed two Continuing Education and Training (CET) campuses which represents positive steps by the Singapore government towards addressing the disruptive impact of technological innovation on future employment (Fuei, 2017). Technological advance is not a zero-sum game, there is a need to help whom affected especially the low skilled ones in reasonable way. As an example, not every lorry driver will or need to become a computer programmer. Perhaps in the future former drivers will use technology to guide and monitor self-driving vehicles or drones to deliver goods (Cedfop (European Center for the Development of Vocational Training), 2017). Finally, it is impossible to ignore the need to design mechanisms that will financially compensate for those adversely affected by the digital revolution (Doménech, García, Montañez, \& Neut, 2017). Public policies can help reducing the unemployment by Public training programs (Mankiw, 2003).

\subsection{New Products and Services}

As a result, from using new technologies, new goods and services will be invented, which will create new tasks and jobs affecting the relationship between automation and unemployment. Also, as some tasks will be automated it will freed-up labors to performs another tasks, the famous example, is the ATM machines which enabled Bank tellers to do other tasks like selling products and services to the customers. Such innovation forces will raise overall incomes and living standards (Brynjolfsson \& Mitchell, 2017). Innovation will increase the overall productivity, this productivity will increase the value of dependent tasks like transportation (Autor, 2015). Steam engine not only power up factories it also enables new means of transportation like railway and steamship. Electricity not only light factories and home, but it also enabled innovation like air conditions. The ICT like the steam engine and electricity are General purpose Technology which is improving overtime and creates innovation. Examples of this, M2M (Machine to Machine) depends on fast internet like 5G. Google car equipped with fast computer and a lot of sensors. Innovations is like a snowball, start small than increase in which one innovation can inspire other innovations in the same field and so on, with also an incremental improvement for the initial innovations. Innovation not only about creating new things, also combining old things can create an innovation. Crowdsourcing is a new technique adopted initially by NASA in which was called open innovation, in which they create a platform to enable others to innovate based on it. Accordingly, it is difficult to predict how the products and the solutions will look like in the future. Obviously, the increased numbers of super computers and interconnected brains will improve the world (Brynjolfsson \& Andrew, 2014).

If the job is fully automated than it will create unemployment, but if the job is partially automated and the production increase with lower costs, and the demand of this product was elastic, increasing of the demand will create more jobs to produce more and more, this is what happened in the $19^{\text {th }}$ century in the cloth industry. Partial automation can create unemployment in case of inelastic demand. New products can shift the workers from declining jobs to more flourish one, like from typesetters to graphic designers (Bessen, 2016). New Technologies can increase the firm's competitive advantage via raising the production while lowering the costs in which the price will decline, and the demand will increase if it is elastic. The increase in the products demand will need more labors which can (partially) compensate for the labor-saving effect of technologies (Arntz, Gregory, \& Zierahn, 2016). Lowering the prices will increase the real wages, which will increase the overall demand including the labors demand (Brynjolfsson \& Andrew, 2014). Economy through increase production as whole will flourish, which will raise consumption, production, and employment (Arntz, Gregory, \& Zierahn, 2019). Increase in income will consequently increase a demand in technology lagging products such as restaurant meals, cleaning services, haircare, and personal fitness which are not subject to automation or replacement. So, rising productivity in certain sectors will lead to the increase demand somewhere else which will boost the employment in traditional jobs (Autor, 2015).

Robotization and automation are time-saving technologies they are not only affect productivity and employment but also will save a lot of time for people. Washing machines, vacuum cleaners and microwaves save time for housewives, which allows them to participate more in the labor force in the second half of the 20th century. The new technology like self-driving cars estimated to save a total of 1,900 billion minutes globally for long-distance commuters every day. Robotization and automation will reduce the complexity of the production which may create an opportunity for producing geographically near the consumer market and metropolitan regions (Csefalvay, 2019). 


\subsection{Complementary Jobs}

Technology both substitute workers and complement others. Automation makes displacement effect for some workers and simultaneously require inputs from other workers, e.g., workers are added to operate and maintain newly introduced automated systems (Arntz, Gregory, \& Zierahn, 2019). Most work processes contain labor and capital; brains and brawn; creativity and rote repetition. When the low skilled workers in many processes complement the technology, the demand for their service will increase (Brynjolfsson \& Andrew, 2014).

In the previous industrial revolutions, the introduction for a new machines created new class of engineers, machinists, repairmen, conductors, back-office workers, and managers who involved in the introduction and the operation of these new technologies. The introduction of industrial robots, digital technologies and computer-controlled machines are again witnessing the emergence of new tasks like programming, data administrators, analysts, and computer support specialists. Automation allows firms to substitute capital for tasks previously performed by labor, while the creation of new tasks which use and operate this technology is a must (Acemoglu \& Restrepo, 2017).

Although ML systems can read medical images, still there is a need for someone to communicate the results to the patients in emotion and professional way (Brynjolfsson \& Mitchell, 2017). Most automated system have a rigid design an example of this machines can assemble a car but in case of accident, human being intervention is a must to remove the broken parts, repair it and re-install it again, this task demand more real-time adaptability than any contemporary robot can cost-effectively perform. "The difference between assembly line production and the in-situ repair highlights the role of environmental control in enabling automation" (Autor, 2015). The following two examples demonstrate how automated-machine and human can work together in one process:

1- Kiva Systems is a Robotics warehousing widely used by Amazon, in which the work is divided between the Robots and the human. When new objective arrived, the robots bring empty shelves to the loading area, in which human load the shelves than the robots carry these shelves and store it based on its demand. When new order to be delivered, the Robots direct the workers to the desired shelves to pick the order, pack it, label it and send it to the delivery place. This system is a mixed work between human and machines, in which the whole process controlled by dispatch software.

2- Google car is operated by computer program, which follows certain rules in normal condition. When unexpected matter happened, like the traffic lights are not working and replaced by guards. The car asks the human to take control.

These examples highlight both the limitations of current technology to accomplish nonroutine tasks, and the need of human ingenuity to overcome these obstacles to complete the required task (Autor, 2015).

\subsection{COVID-19}

COVID-19 has an overall impact on unemployment and on specific occupation which demand high interaction with people, part of them was mandatory to continue like health care workers and physician. Other jobs which was less important and forced to stop work. People with nature of office work which can be done from home through telecommuting devices was in safe zone against unemployment. On the other hand, there was more demand in healthcare workers and delivery company, Amazon Announce its need for 100,000 new job with increased pay $\$ 2$ per hour to meet the increased demand on online shopping (Béland, Brodeur, \& Wright, 2020). After COVID-19 containment the normal life will not become the same as before. Several lessons learned and habits whether it is related to customers new behaviors or the way he was served. (Alatovic, Chhaya, Juneja, Smaje, \& Sukharevsky, 2020). Most companies started to implement working from home policies and business owners and managers started to assess the new normal after the pandemic. Permanent job loss is occurring slowly, with each day bringing new numbers. The future is susceptible according to the duration will be taken in this pandemic affecting the newly created business to absorb the new entrants and the re-entering of the work force which increase the probability for long term unemployment (Stevenson, 2020). Remedies would include upskilling and reskilling, helping individuals exploring potential plans, involves moving from specific specialization to more generalization. We can see how teachers fast adopted to online learning with little guidance and preparation time (Hite \& McDonald, 2020).

Several Aspects appeared during the COVID-19 if continued it will affect the overall employment in a negative way, one of them is Telepresence which proved that it will not only reduce costs by removing employee expenses to reach and stay in the office, but it will also increase the efficiency by removing the transportation time which is on the average 54 Minutes per day in USA. Telepresence most probably will be continued after COVID-19 for high educated workers whose work is easily can be done remotely (Autor \& Reynolds, 2020). To keep the momentum gained from the pandemic leaders should focus on Hire when others are not, especially 
experts in big Data, Machine learning, data science and Reskill/Upskill workers (Henke, Puri, \& Saleh, 2020).

Based on the change of customer behavior, New consumer groups tried digital products for the first time such as Video Chat to hold their business meetings from home. This is increase also happened in B2B (Fitzpatrick, Gill, Ari Libarikian, Smaje, \& Zemmel, 2020).

As most of the countries around the world enforce a lockdown on its citizens, it creates a huge demand on digital services. Ordering groceries and telemedicine become a norm and hundreds of millions of employees relaying on telecommunication services (mobile\& fixed broadband), as well as collaborative tools to perform their jobs. Studying the new behaviors require attention in several fields to satisfy the customers new needs (Alatovic, Chhaya, Juneja, Smaje, \& Sukharevsky, 2020).

COVID-19 not only affect the C2B with new digital habits it is also affects B2B business operations, which will look fundamentally different from what they were before the pandemic. Sales interaction will be mainly remotely through digital channels like videoconference, webinar, phone, human chatbot, and other digital means to perform the sales process which was already exist but currently being used during the pandemic with high acceleration rates, like omnichannel selling, tech-enabled selling and e-commerce (Gavin, Harrison, Plotkin, Spillecke, \& Stanley, 2020).

As COVID-19 had a direct negative impact on the employment in several sectors and industries, it creates a new opportunities as for ex, the reduction of the transportation time through allowing working from home, allows the employees to have more time to perform a reskilling and upskilling for their current skills. Also, COVID-19 accelerate the introduction of new digital solutions as well as promote the usage of old ones, like digital banking in which reduce current workers and introduce new ones to support these new systems.

\subsection{Research Questions and Hypotheses}

Major Q(1): To what extent Automation and Artificial intelligence will cause an unemployment in Mobile operators in Egypt?

Minor Q(2): Can COVID-19 in Egypt considered as a Catalyst to Upskilling and Reskilling?

(H1o): Employees in high-risk categories are not performing Reskilling activities more than employees in Low-Risk category.

(H1a): Employees in high-risk categories are performing Reskilling activities more than employees in Low-Risk category.

(H2o): Employees in Low-risk categories are not performing Upskilling activities more than employee in High-Risk category.

(H21): Employees in Low-risk categories are performing Upskilling activities more than employees in High-Risk category.

Minor Q(3): To what extent Introducing of new products and services will Moderate the relation between Automation\& Artificial intelligence and unemployment?

Minor Q(4): To what extent the Introducing of new complementary tasks to support the new automated system will Moderate the relation between Automation\& Artificial intelligence and unemployment?

\section{Methodology}

$41 \%$ of the Technology staff in the Mobile operators will be on Risk of unemployment because of the Digital Transformation. COVID-19 will add another $8 \%$ Risk, as certain un-automatable tasks, when performed from home during COVID-19 was performed better. This can create efficiencies and reduce the no of people performing these tasks (Elsafty \& Elzeftawy, 2021). Several Moderating variables May affect the relation between the independent variable (Automation \&AI) and the dependent variable (Unemployment).

The Research philosophy is Positivism, the approach is deductive, the methodological is mixed methods quantitative and Qualitative Research on which will use several Quantitative and qualitative techniques to collect the data, the strategy will be non-contrived, zero control and several cross-sectional field study (Sunders, Lewis, \& Thronthill, 2012, p. 164).

Our quantitative method will be based on survey through questionnaires to Engineers working in a technical department in Mobile Operator, and we will use the following quantitative analysis methods:

- Regression Analysis

- Correlations Analysis 
- Test of Normality

- Descriptive Analysis (mean, median and mode)

- Independent Samples T-test

Our Qualitative method will be based on Structured interviews with a non-probability sample of Technology Managers, as the Sampling Criteria is Judgmental Sampling.

\section{Dependent Variables}

VAR (Y): Unemployment is when a person who is seeking a work to fulfill his needs is unable to find a work.

Independent variable

VAR (X1): Automation and AI, which is the use of intelligent machines to perform a tasks or full job, which was done before by a human being.

\section{Moderating variables}

VAR (Mo1): COVID-19, which may act as a catalyst to Reskilling and Upskilling by saving time through WFH.

VAR (Mo2): Reskilling \& Upskilling, in which Upskilling is learning new competencies to stay in the current role and Reskilling is learning new sets of competencies, to enable performing a completely new role.

VAR (Mo3): New products and services, which arise after the adoption of new technology.

The New products and services will create new tasks and jobs.

VAR (Mo4): Complementary jobs, is the new created jobs arise to support the new automated systems.

\subsection{Theoretical Framework}

The theoretical framework is illustrated in figure 4.

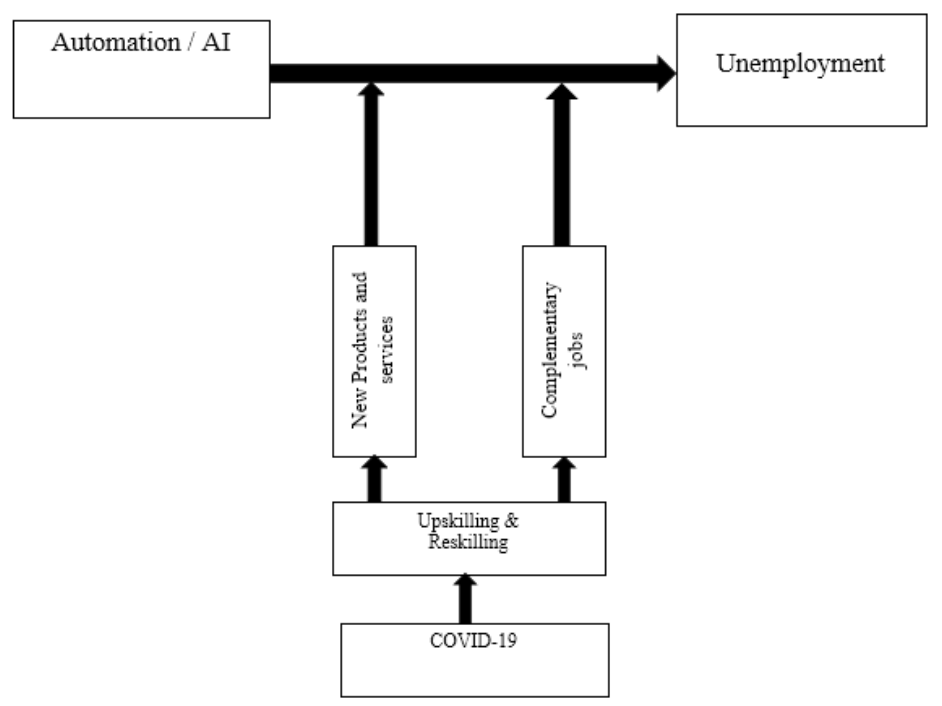

Figure 4. Theoretical framework

\subsection{Answering The Research Questions and the Hypotheses}

To answer Major (Q1): we will make a survey through questionnaires, to measure what is the percentage of performing Un-automatable tasks from the whole tasks performed by a Random sample of employees working in the technology department in one of the Mobile operators in Egypt.

Sampling method: Probability Sampling, for 100 Engineers working on the technology Department in one of the Mobile operators, Confidence level 95\%, error 10\%.

By doing this we can determine the no of employee under Risk of automation \& AI. 


\section{Data Collection Steps}

1- By combining the "Engineering-Bottlenecks", which defined by Carl Benedikt Frey and Michael A. Osborne, 2013 and Other tasks defined by Katharina Dengler, Britta Matthes and Wiebke Paulus, 2014 in which they use the assignment of activities explained by Alexandra Spitz-Oener for non-automatable tasks and categorize the non-automatable tasks as: analytical non-routine tasks, interactive non-routine tasks, we reach the following 20 Un-automatable tasks as illustrated in table 2 (Elsafty \& Elzeftawy, 2021).

Table 2. Un-automatable tasks and skills

\begin{tabular}{|c|c|c|c|}
\hline & Tasks/Skills & & Tasks/Skills \\
\hline 1 & $\begin{array}{l}\text { Technical skills } \\
\text { solving Technical problems which required Manual intervention in limited area spaces and } \\
\text { sometimes need finger dexterity }\end{array}$ & 11 & Customer advisor \\
\hline 2 & $\begin{array}{l}\text { Problem solving skills } \\
\text { Ability to solve problems which occurs for the first time }\end{array}$ & 12 & Doing Research \\
\hline 3 & $\begin{array}{l}\text { Learning skills } \\
\text { Frequent learning and applying of new things }\end{array}$ & 13 & Analyzing Data \\
\hline 4 & Setting up plans & 14 & $\begin{array}{l}\text { Constructions of new } \\
\text { assets }\end{array}$ \\
\hline 5 & Managing duties according to plan & 15 & Designing and sketching \\
\hline 6 & Team management & 16 & Software development \\
\hline 7 & Teaching and instructing people & 17 & $\begin{array}{l}\text { lobbying with other } \\
\text { parties }\end{array}$ \\
\hline 8 & Making speeches or presentation & 18 & Training people \\
\hline 9 & Selling a product or service & 19 & Doing Advertisement \\
\hline 10 & Negotiation to buy product or service from suppliers & 20 & employing people \\
\hline
\end{tabular}

2- As indicated from my previous research (Elsafty \& Elzeftawy, 2021). Certain tasks are not applied on the technology department in Mobile operators (which the sample came from) like Selling a product or service, Customer advisor, Constructions of new assets, lobbying with other parties and doing advertisement. Other tasks like employing people and training take a small percentage like 5 to $15 \%$ from few people so will be neglected. Another task like Technical skills is taking $100 \%$ from certain engineers and technician and it is potential to be managed services and to be excluded from the main task force. Table 2 will be modified to be suitable for the nature of work of our sample as illustrated in Table 3.

Table 3. Un-automatable tasks and skills (modified)

\begin{tabular}{llll}
\hline & Tasks/Skills & Tasks/Skills \\
\hline 1 & $\begin{array}{l}\text { Problem solving skills } \\
\text { Ability to solve problems which occurs for the first time }\end{array}$ & 7 & Making speeches or presentation \\
2 & $\begin{array}{l}\text { Learning skills } \\
\text { Frequent learning and applying of new things }\end{array}$ & 8 & Negotiation to buy product or service from suppliers \\
3 & Setting up plans & 9 & Doing Research \\
4 & Managing duties according to plan & 10 & Analyzing Data \\
5 & Team management & 11 & Designing and sketching \\
6 & Teaching and instructing people & 12 & Software development \\
\hline
\end{tabular}

To prevent people from marking all activities as it part from their activities as tested in several samples, we add another 8 disguised common tasks in the technology functions in the mobile operators to table 5 . The 8 disguised tasks are illustrated in Table 4. 
Table 4. Disguised additional tasks

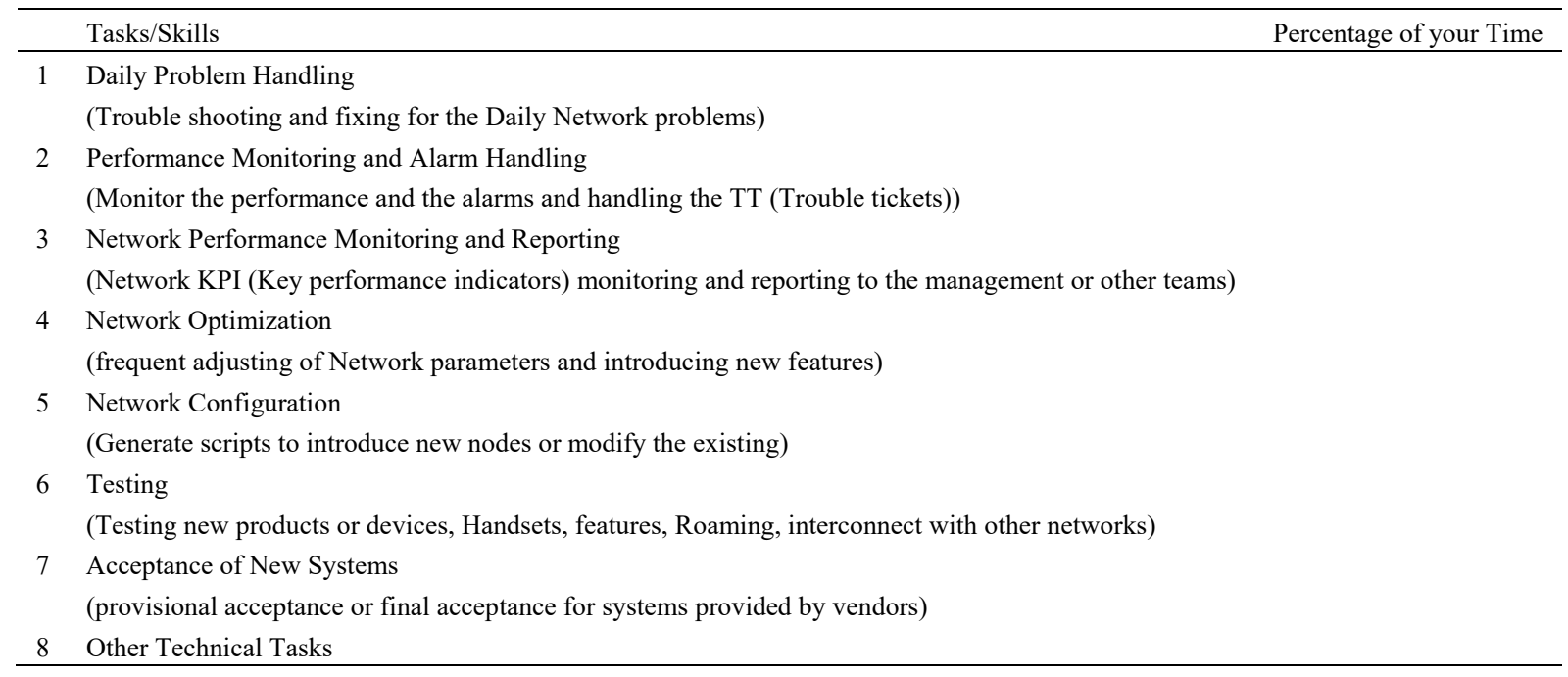

By this we will have a table of 20 tasks, in which will be used as the core part in the questionnaire through the survey and the interviews. After that we will collect the answers and analyze them statistically using IBM SPSS program V27.

To answer Q1\&2: The Questionnaires to answer Q1, Q2 are illustrated in Appendix-1.

To Accept or Reject (H10, H20): We divided the data obtained to answer question 1 to two equal groups, high risk group in which $40 \%$ (the risk median) of their tasks are potential for automation, and medium/low risk group in which their automatable tasks are less than $40 \%$. They were asked the questionnaire on Appendix- 2 than we collect the answers and examined them statistically, using "Independent-Samples T-test.

To answer Q3: Structured interviews with a non-probability sample of Technology Managers to Determine whether and how much the introduction of new digital products create new tasks. and what is the type of these tasks and how we can map it with computer bottlenecks skills and tasks. The reason of making structured interview and not sending a questionnaire mail is the need to introduce the subject to the audience and to grasp more info as Most of them might have information about the new technology but did not think before about the consequence and the need for hiring to develop and operate these products on the future.

The interviews were done by the researcher himself according to planned meetings with the experts at their convenience, they were offered the choice to mention their names or to stay anonymous. The interviews were planned from 30 to 45 minutes and were ended by grateful thanks from the researchers.

Sampling method: Non-Probability Sampling, Sampling Criteria: Judgmental Sampling.

The Questionnaire in Appendix 3.

To answer Q4: Structured interviews with a non-probability sample of Managers who will be asked about new jobs created to support or maintain (complementary jobs) new created automated systems. The interviews were done by the researcher himself according to planned meetings with the experts at their convenience, they were offered the choice to mention their names or to stay anonymous. The interviews were planned from 30 to 45 minutes, and to be ended by grateful thanks from the researchers.

Sampling method: Non-Probability Sampling, Sampling Criteria: Judgmental Sampling.

The Questionnaire in Appendix 4.

\section{Results \&Analysis}

A statistical analysis of the used sample as illustrated in the tables $(10.11,12,13,14)$ gave the following Results:

1 - The model is significant $<.05$ which indicate a good degree of prediction.

2- SW Development is not highly correlated with any task, which mean SW Development is a specialization in this organization.

3- The Data are Normally Distributed. 
Linear Regression Analysis: The output of the SPSS program is illustrated in Table 10.

Table 10. Regression analysis (1)

\begin{tabular}{|c|c|c|c|c|c|}
\hline & $\mathrm{B}$ & Std. Error & Beta & $\mathrm{t}$ & Sig. \\
\hline (Constant) & 10.46 & 1.88 & & 5.563 & 0 \\
\hline Learning skills & 1.015 & 0.139 & 0.226 & 7.33 & 0 \\
\hline Setting up plans & 1.033 & 0.135 & 0.271 & 7.653 & 0 \\
\hline Managing duties according to plan & 0.876 & 0.089 & 0.317 & 9.816 & 0 \\
\hline Team management & 0.873 & 0.065 & 0.454 & 13.398 & 0 \\
\hline Teaching and instructing people & 1.049 & 0.096 & 0.331 & 10.94 & 0 \\
\hline Making speeches or presentation & 0.889 & 0.141 & 0.192 & 6.288 & 0 \\
\hline Negotiation to buy product or service from suppliers & 0.908 & 0.123 & 0.229 & 7.411 & 0 \\
\hline Doing Research & 1.12 & 0.153 & 0.221 & 7.323 & 0 \\
\hline Analyzing Data & 1.021 & 0.072 & 0.453 & 14.189 & 0 \\
\hline Designing and sketching & 0.843 & 0.118 & 0.215 & 7.159 & 0 \\
\hline Software development & 0.894 & 0.066 & 0.419 & 13.453 & 0 \\
\hline
\end{tabular}

a. Dependent Variable: Non-Automation Risk

The model is significant $<.05$ which indicate a good degree of prediction.

The significant of the model appear in the ANOVA table which illustrated in table 11 as part from the regression analysis.

Table 11. Linear regression analysis (2)

\begin{tabular}{llllll}
\hline Model & Sum of Squares & $\mathrm{df}$ & Mean Square & F & Sig. \\
\hline Regression & 40647.275 & 11 & 3695.207 & 99.944 & 0.00 \\
Residual & 3327.552 & 90 & 36.973 & & \\
Total & 43974.827 & 101 & & & \\
\hline
\end{tabular}

We will then examine the correlation between the tasks:

Correlations Analysis: The results of correlation analysis using SPSS in table 12.

Table 12. Correlation analysis

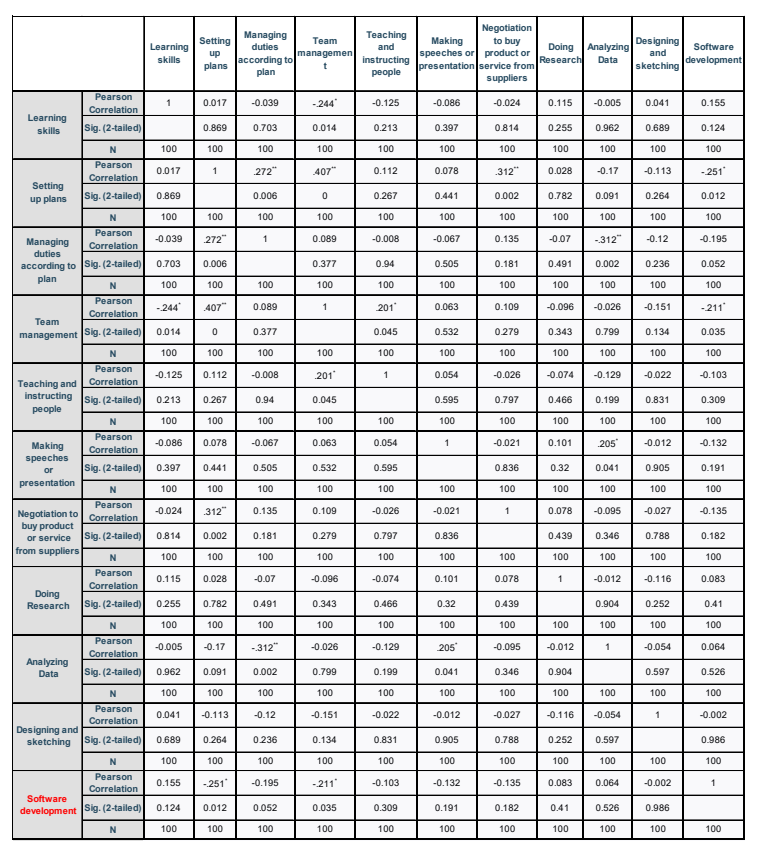


Important Finding: SW Development is not highly correlated with any task: which mean SW Development is a specialization

Table 13. Skewness and Kurtosis analysis

\begin{tabular}{lll}
\hline Automation Risk & & \\
\hline $\mathrm{N}$ & Valid & 100 \\
& Missing & 0 \\
Median & & $40.00 \%$ \\
Skewness & 0.241 \\
Std. Error of Skewness & 0.241 \\
Kurtosis & -0.428 \\
Std. Error of Kurtosis & 0.478 \\
\hline
\end{tabular}

Notes. Divide skewness statistic/standard error $=1$

Divide kurtosis statistic/standard error $=-.89$

If both values between -1.96 and +1.96 than the sample is normally distributed.

Table 14. Test of normality

\begin{tabular}{llllll}
\hline $\begin{array}{l}\text { Kolmogorov-Smirnov }^{\mathrm{a}} \\
\text { Statistic }\end{array}$ & $\mathrm{df}$ & Sig. & $\begin{array}{l}\text { Shapiro-Wilk } \\
\text { Statistic }\end{array}$ & df & Sig. \\
\hline 0.065 & 100 & $.200^{*}$ & 0.983 & 100 & 0.221 \\
\hline
\end{tabular}

If Shapiro Sig $>.0 .05$ than the data are normally distributed.

\subsection{Sample Characteristics}

A Saphiro-wilk test ( $\mathrm{p}>$.05) (Wilk, Shapiro, \& B, 1965) and a visual inspection of their histograms, Normal Q-Q plots and box plots showed that Automation Risk were approximately normally distributed, with a Skewness of $0.241(\mathrm{SE}=0.241)$ (Doane \& Seward, 2011) and a Kurtosis of -0.428 (SE=0.478) (Field, 2009).

\subsection{The Data collected to answer Q1}

In answering the involvement of the 100 employees in the 12-unautomatable tasks we had the following data in table 15

Table 15. 100 Aggregated 100 Employee response to Q1

\begin{tabular}{|c|c|c|}
\hline & Tasks/Skills & $\begin{array}{l}\text { Average Percentage of the Time of } 100 \\
\text { Employees }\end{array}$ \\
\hline 1 & $\begin{array}{l}\text { Complex Problem solving } \\
\text { (Solving New problems appeared for the first time) }\end{array}$ & $7.5 \%$ \\
\hline 2 & $\begin{array}{l}\text { Frequent learning and applying of new things } \\
\text { (continuous learning of new systems and applying my learning on these systems) }\end{array}$ & $5.6 \%$ \\
\hline 3 & $\begin{array}{l}\text { Setting up Plans } \\
\text { (Business Planning and budgeting, yearly or long term) }\end{array}$ & $4.1 \%$ \\
\hline 4 & $\begin{array}{l}\text { Managing duties according to plan } \\
\text { (Project Management for one or more projects) }\end{array}$ & $7.2 \%$ \\
\hline 5 & $\begin{array}{l}\text { Team management } \\
\text { (Manage or supervise a team) }\end{array}$ & $8.0 \%$ \\
\hline 6 & $\begin{array}{l}\text { Teaching people } \\
\text { (Mentor Junior staff, provide them with the necessary knowledge to perform their tasks) }\end{array}$ & $5.7 \%$ \\
\hline 7 & $\begin{array}{l}\text { Making presentation } \\
\text { (prepare and doing presentation for upper management) }\end{array}$ & $4.4 \%$ \\
\hline 8 & Negotiation to buy product or service from suppliers & $1.9 \%$ \\
\hline
\end{tabular}




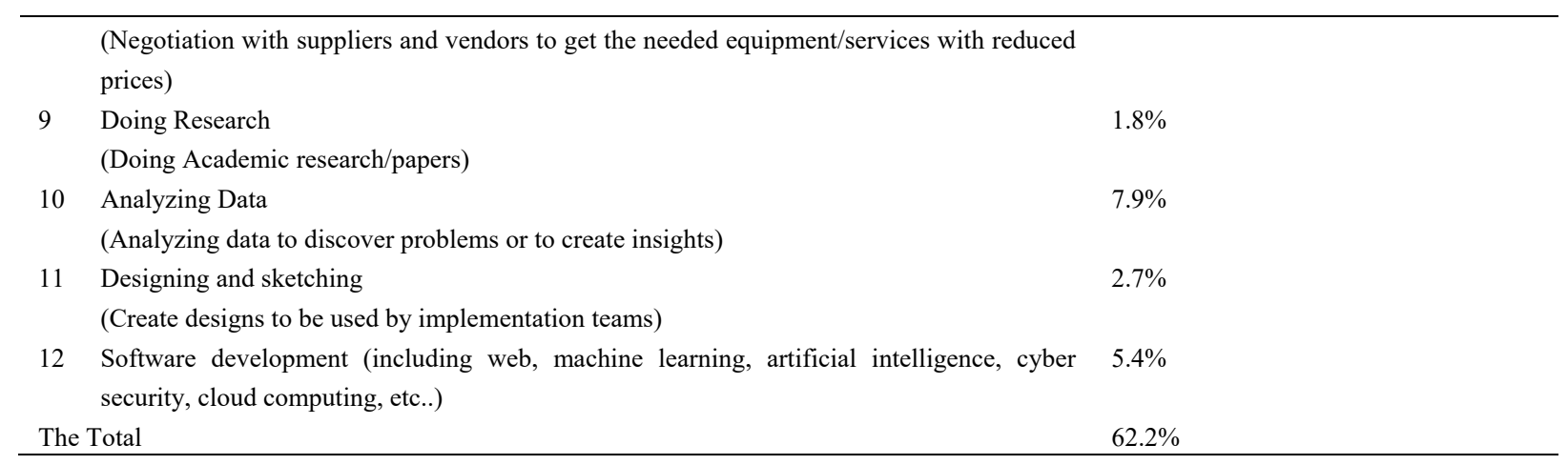

The Output from the descriptive analysis using SPSS program as illustrated in table 16and table 17.

Table 16 Descriptive analysis (1)

\begin{tabular}{llllll}
\hline & $\mathrm{N}$ & Minimum & Maximum & Mean & Std. Deviation \\
\hline Automation Risk & 100 & $0.00 \%$ & $95.00 \%$ & $37.85 \%$ & $21.07 \%$ \\
Valid N (listwise) & 100 & & & & \\
\hline
\end{tabular}

Notes. The mean is $37.85 \%$ and the Median is $40 \%$

$51 \%$ from the sample is found to be above the mean value

The Answer for Q1: The technology department HOD's state that 41\% of the Technology staff in the Mobile operators will be on Risk of unemployment because of the Digital Transformation (Elsafty \& Elzeftawy, 2021). After Deep dive questionnaires to 100 Engineers as a sample, we found that $38 \%$ of the tasks they are performing, is under the risk of automation and we found that $51 \%$ of the employees, more than $40 \%$ (the median) of their current tasks are subject to automation.

The Answer for Q2: People believe that WFH resulted from COVID-19 precautions, will have a significant positive impact on helping people performing Reskilling and Upskilling (The Mean is 3.8, the Median is 4 and the mode of 4 out of 5 ).

The data for Q2 was collected and analyzed using SPSS descriptive analysis as shown in table 17

Table 17 Descriptive Analysis for q2 (1)

\begin{tabular}{|c|c|c|}
\hline \multicolumn{3}{|c|}{ WFH support Learning } \\
\hline $\mathrm{N}$ & Valid & 100 \\
\hline & Missing & 0 \\
\hline \multicolumn{2}{|c|}{ Mean } & 3.8 \\
\hline \multicolumn{2}{|c|}{ Std. Error of Mean } & 0.104 \\
\hline \multicolumn{2}{|c|}{ Median } & 4 \\
\hline \multicolumn{2}{|c|}{ Mode } & 4 \\
\hline
\end{tabular}

To Accept or Reject Hypothesis H1o: We divided the answer of the people regarding the Reskilling activities into 2 groups. Group1 is the group who has high risk to Automation (as per the answer of the first question we have 51 ) has $40 \%$ (40 was the median) and more of their tasks are potential for automation. Group 2 is the group who has low risk to Automation (as per the answer of the first question we have 49 ) has less than $40 \%$ of their tasks are potential for automation. We omit 2 answers from the first group randomly to have equal samples, then we used the SPSS program to Analyze an independent Samples T-test.

we aggregate all the Variables mean in one variable (Reskilling Mean) we had the sig (2-tailed) $0.528>.05$ Not statistically Significant. the results shown in table 18 
Table 18 Independent samples test to test hypothesis 1 (2)

\begin{tabular}{|c|c|c|c|c|c|c|c|c|c|c|}
\hline & & \multicolumn{2}{|c|}{ Levene's Test for } & \multicolumn{7}{|c|}{ t-test for Equality of Means } \\
\hline & & \multicolumn{9}{|c|}{$\begin{array}{l}\text { Equality of } \\
\text { Variances }\end{array}$} \\
\hline & & \multirow[t]{2}{*}{$\mathbf{F}$} & \multirow[t]{2}{*}{ Sig. } & \multirow[t]{2}{*}{$\mathbf{t}$} & \multirow[t]{2}{*}{ df } & \multirow[t]{2}{*}{$\begin{array}{l}\text { Sig. } \\
\text { (2-tailed) }\end{array}$} & \multirow[t]{2}{*}{$\begin{array}{l}\text { Mean } \\
\text { Difference }\end{array}$} & \multirow[t]{2}{*}{$\begin{array}{l}\text { Std. Error } \\
\text { Difference }\end{array}$} & $\begin{array}{l}95 \% \\
\text { Interval } \\
\text { Difference }\end{array}$ & $\begin{array}{c}\text { Confidence } \\
\text { of the }\end{array}$ \\
\hline & & & & & & & & & Lower & Upper \\
\hline \multirow[t]{2}{*}{$\begin{array}{l}\text { Reskilling } \\
\text { Mean }\end{array}$} & $\begin{array}{l}\text { Equal } \\
\text { variances } \\
\text { assumed }\end{array}$ & 1.012 & 0.317 & 0.633 & 98 & 0.528 & 0.05115 & 0.08082 & -0.10924 & 0.21154 \\
\hline & $\begin{array}{l}\text { Equal } \\
\text { variances } \\
\text { not } \\
\text { assumed }\end{array}$ & & & 0.63 & 93.236 & 0.53 & 0.05115 & 0.08113 & -0.10995 & 0.21225 \\
\hline
\end{tabular}

Note. $0.528>.05$ Not statistically Significant.

\section{Fail to reject H1o.}

The statistical analysis results failed to reject H1o. So, there is no difference between the high-risk group and the low-risk group in terms of Reskilling activities they are doing.

To Accept or reject Hypothesis H2o: We divide the answer of the people regarding the Reskilling activities into 2 groups. Group 1 is the group who has high risk to Automation (as per the answer of the first question we have 51) as $40 \%$ and more of their tasks are potential for automation. Group2 is the group who has low risk to Automation (as per the answer of the first question we have 49 ) as less than $40 \%$ of their tasks are potential for automation. We omit 2 answers from the first group randomly to have equal samples, then use the SPSS program to Analyze an independent Samples T-test. We aggregate all the Variables mean in one variable (Upskilling Mean) we had the results shown in table 19.

\subsection{Independent Samples Test}

Table 19 Independent samples test to test hypothesis 2 (2)

\begin{tabular}{|c|c|c|c|c|c|c|c|c|c|c|}
\hline & & \multirow{3}{*}{$\begin{array}{l}\text { Levene's } \\
\text { Equality } \\
\text { Variances }\end{array}$} & \multirow{3}{*}{$\begin{array}{l}\begin{array}{r}\text { Test for } \\
\text { of }\end{array} \\
\text { Sig. }\end{array}$} & \multicolumn{7}{|c|}{ t-test for Equality of Means } \\
\hline & & & & $\mathrm{t}$ & $\mathrm{df}$ & $\begin{array}{l}\text { Sig. } \\
\text { (2-tailed) }\end{array}$ & $\begin{array}{l}\text { Mean } \\
\text { Difference }\end{array}$ & $\begin{array}{l}\text { Std. Error } \\
\text { Difference }\end{array}$ & $\begin{array}{l}95 \% \\
\text { Interval } \\
\text { Difference }\end{array}$ & $\begin{array}{l}\text { Confidence } \\
\text { of the }\end{array}$ \\
\hline & & & & & & & & & Lower & Upper \\
\hline \multirow{3}{*}{$\begin{array}{l}\text { Upskilling } \\
\text { Mean }\end{array}$} & Equal & 1.497 & 0.224 & 1.051 & 98 & 0.296 & 0.10398 & 0.09892 & -0.09232 & 0.30029 \\
\hline & $\begin{array}{l}\text { variances } \\
\text { assumed }\end{array}$ & & & & & & & & & \\
\hline & $\begin{array}{l}\text { Equal } \\
\text { variances } \\
\text { not assumed }\end{array}$ & & & 1.046 & 91.179 & 0.298 & 0.10398 & 0.09939 & -0.09344 & 0.3014 \\
\hline
\end{tabular}

Note. $0.296>.05$ Not statistically Significant.

\section{Fail to reject $\mathbf{H 2 0}$.}

The statistical analysis results failed to reject H2o. So, there is no difference between the high-risk group and the low-risk group in terms of Upskilling activities they are doing.

The Conclusion of testing Hypothesis 1,2: There is no difference between the high-risk group and the low-risk group in terms of Reskilling or Upskilling activities they are doing. This also confirmed from the analysis of the info collected in table 8. The High-risk group did 115 self-training, engaged in 66 training courses, and got 21 
certificates, in SW development they did 5 self-training, engaged in 13 training courses, and got 6 certificates. The low-risk group did 110 self-training, engaged in 70 training courses, and got 26 certificates in SW development they did 4 self-training, engaged in 8 training courses, and got 4 certificates. There is a similarity between the 2 groups, which can be either a lake of awareness from the high-risk group about the risk or more motivation from the low-risk group towards personal development. However, both groups were not focused on SW development.

To Answer (Q3): We interviewed the Chief Information Officer in one of the Major Mobile operators in Egypt officer whom in charge of the delivery of digital products and services to the customers.

The Answer of (Q3): New products like Mobile wallet and New services introduced via Mobile App, increase the manpower of the technology department of the mobile operators by almost $5 \%$, however the new jobs cannot fill from insiders who did upskilling and Reskilling, in which external hiring was mandate.

To Answer (Q4): We interviewed The Network Operation Manager and the Radio Digital Manager who managed to introduce new automated systems in one of the Major Mobile operators in Egypt.

The answer of $(\mathbf{Q} 4)$ : The Analysis of the interviews indicate that, the complementary tasks will contribute with a small percentage from the total population under the study. In which will add almost 13 new jobs to 1020 Risky jobs (51\% of 2000 employee) in which 4 of them will be outsiders. This will make the risk mitigation is $9 / 1020=$ almost $1 \%$ saving and it mostly need a SW development skill.

\subsection{Summary of the Analysis}

The summary of the analysis of the results are illustrated in figure 5 .

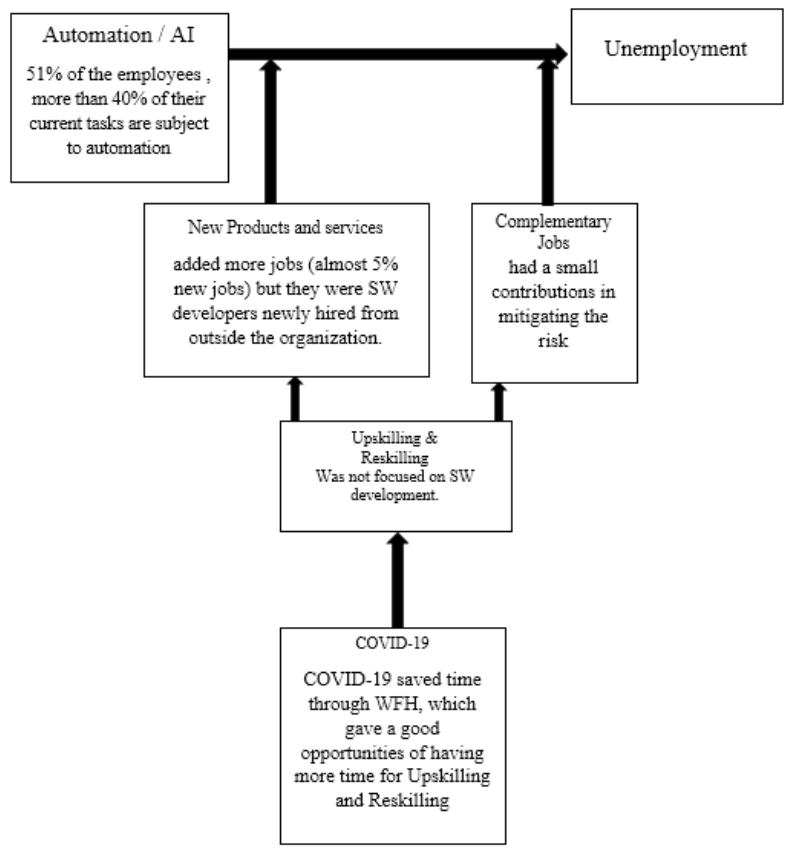

Figure 5. The Results of the study

\section{Discussion \& Conclusion}

The technology department HOD's state that $41 \%$ of the Technology staff in the Mobile operators will be on Risk of unemployment because of the Digital Transformation (Elsafty \& Elzeftawy, 2021). After Deep dive questionnaires to 100 Engineers in the technology department in one of the leading Telecom operators in Egypt as a sample, we had almost similar results to what we have in the previous paper. We found that $38 \%$ of the tasks they are performing, is under the risk of automation and we found $51 \%$ of the employees, more than $40 \%$ of their current tasks are subject to automation. Employees agreed that COVID-19 saved time through WFH, which gave a good opportunities for them to have more time for Upskilling and Reskilling with a score 3.8 out of 5. We divide the sample after the first analysis to 2 categories, High Risk group who $40 \%$ and more of their tasks are subject to Automation, and low risk group. Almost the 2 groups made the same behavior towards Upskilling and 
reskilling. Also, The High-risk group did 115 self-training, engaged in 66 training courses, and got 21 certificates, in SW development they did 5 self-training, engaged in 13 training courses, and got 6 certificates. The low-risk group did 110 self-training, engaged in 70 training courses, and got 26 certificates in SW development they did 4 self-training, engaged in 8 training courses, and got 4 certificates. There is a similarity between the 2 groups, which can be either a lake of awareness from the high-risk group about the risk or more motivation from the low-risk group towards personal development. However, both groups were not focused on SW development. Complementary tasks for the new automated systems, had a small contribution in mitigating the risk (less than one percent new jobs), however new digital products and services created added more jobs (almost $5 \%$ new jobs) but they were SW developers newly hired from outside the organization. New Complementary jobs for new automated systems and new jobs created from the new products and services, in the mobile operator technology department under the study were mainly need SW development skills which was found not highly correlated with any other skills in the performed survey.

In brief, Mobile Operators engineers are facing a high Risk of unemployment due to digital transformation, and COVID-19 will increase the risk. Employees whom jobs under high risk, their pattern of behavior towards Reskilling and Upskilling is the same as employees whom facing a lower risk which should be higher as most of the employees agreed that COVID-19 will provide more time for training by reducing the time and the fatigue from the transportation. Reskilling and Upskilling of the current workforce will not be effective unless it is planned according to the new created jobs from introducing new products and services or complementary jobs for newly introduced automated systems as the new created jobs are mainly SW developers, which does not have enough shares in the current personal development activities.

\section{Future Research}

Study the Role of the Governmental entities to Mitigate the unemployment Risk and to support the people to overcome the risk. Study the Capabilities of the education systems to supply new labors with future digital skills. Study the Impact of digital transformation on another industry or another field like agriculture and trading. Study the Impact on people who was subjected to unemployment due to digitalization.

\section{References}

Acemoglu, D., \& Restrepo, P. (2017, June). The Race Between Machine and Man: Implications of Technology for Growth, Factor Shares. Cambridge. Retrieved from http://www.nber.org/papers/w22252

Alatovic, T., Chhaya, M., Juneja, S., Smaje, K., \& Sukharevsky, A. (2020, April). Driving digital change during a crisis: The chief digital officer and COVID-19. McKinsey.

Arntz, M., Gregory, T., \& Zierahn, U. (2016, May 13). The Risk of Automation for Jobs in OECD Countries: AComparative Analysis. Paris, France: OECD Social, Employment and Migration Working Papers.

Arntz, M., Gregory, T., \& Zierahn, U. (2019, June). Digitalization and the future of work: Macroeconomic consequences. Mannheim, Germany: Leibniz Centre for European Economic Research.

Autor, D. H. (2015). Why Are There Still So Many Jobs? The History and Future of Workplace Automation. Journal of Economic Perspectives, 29(3), 3-30.

Autor, D., \& Reynolds, E. (2020). The Nature of Work after the COVID Crisis: Too Few Low-Wage Jobs. The Hamilton Project.

Béland, L. P., Brodeur, A., \& Wright, T. (2020). The Short-Term Economic Consequences of COVID-19: Exposure to Disease, Remote Work and Government Response. Bonn, Germany.

Bessen, J. (2016). How Computer Automation Affects Occupations: Technology, jobs, and skills. Boston: Boston University School of Law.

Bonekamp, L., \& Sure, M. (2015). Consequences of Industry 4.0 on Human Labour and Work Organisation. Journal of Business and Media Psychology, 6(1), 33-40.

Brynjolfsson, E., \& Andrew, M. (2014). The Second Machine Age. London: W. W. Norton \& Company.

Brynjolfsson, E., \& Mitchell, T. (2017, Dec 21). What can machine learning do? Workforce implications. Science, 1530-1534.

Cedfop (European Center for the Development of Vocational Training). (2017). People, Machines, Robots and Skills. Greece.

Csefalvay, Z. (2019). What are the policy options? A systematic review of policy responses to the impacts of robotisation and automation on the labour market. JRC. 
Dengler, K., Matthes, B., \& Wiebke, P. (2014). Occupational Tasks in the German Labour Market. FDZ method reports.

Doane, D. P., \& Seward, L. E. (2011). Measuring Skewness: A Forgotten Statistic? Journal of Statistics Education, 19.

Doménech, R., García, J. R., Montañez, M., \& Neut, A. (2017). How vulnerable is Spanish employment to the digital revolution? Madrid, Spain: BBVA Research.

ElSafty, A. (2018). Business Research Methods. Egypt: Lecture Notes, Lecture One.

Elsafty, A. (2018). Lecture 2: Scientific Business Research Problem Definition [PowerPoint slides]. Retrieved from Maastricht School of Management, MBA Degree.

Elsafty, A. (2018). Lecture 2: Scientific Business Research Problem Definition [Lecture]. Retrieved from Maastricht School of Management, MBA Degree.

Elsafty, A., \& AlNawaly, A. (2020). Role of Co-Working Spaces' Services in Entrepreneurs Growth in Upper Egypt, The Case of Step Co-Working Space. Business and Management Studies, 6(2). https://doi.org/10.11114/bms.v6i2.4899

Elsafty, A., \& Elshahed, M. (2021). The Changes in Online Buying Intention as a Determinant of Behavior During COVID-19 Pandemic in the Ready-Made Garments Industry in Egypt. International Journal of Business and Management, 16(5), 1-24. https://doi.org/10.5539/ijbm.v16n5p1

Elsafty, A., \& Elzeftawy, A. (2021). The New Era of Digital Transformation and COVID-19 Effect on The Employment in Mobile Operators in Egypt. Business and Management Studies, 7(1), 1-21. https://doi.org/10.11114/bms.v7i1.5087

Elsafty, A., \& Osman, M. (2021). The Impact of COVID-19 on the Efficiency of Packing Lines in Pharmaceutical Manufacturing Sites in Egypt. International Journal of Business and Management, 16(7), 57-72. https://doi.org/10.5539/ijbm.v16n7p57

Elsafty, A., \& Ragheb, M. (2020). Role of Human Resource Management towards Employees Retention during Covid-19 Pandemic. Business and Management Studies, 6(2). https://doi.org/10.11114/bms.v6i2.4899

Elsafty, A., \& Tahon, A. (2020). Exploring Impact of Corporate Social Responsibility on Organizational Performance, the Case of Turkish Islamic Banks. Business and Management Studies, 7(1), 1-21. https://doi.org/10.11114/bms.v7i1.5087

Elsafty, A., Abadir, D., \& Shaarawy, A. (2020). How Does the Entrepreneurs' Financial, Human, Social and Psychological Capitals Impact Entrepreneur'S Success? Business and Management Studies, 6(3), 55-71. https://doi.org/10.11114/bms.v6i3.4980

Elsafty, A., Elbouseery, I., \& Shaarawy, A. (2020). Factors Affecting the Behavioral Intention to Use Standalone Electronic Personal Health Record Applications by Adults in Egypt. Business and Management Studies, 6(4), 14-36. https://doi.org/10.11114/bms.v6i4.5066

Elsafty, A., Elsayed, H., \& Shaaban, I. (2020). A Business Analysis Perspective for Engineering Education in Egypt. Journal of Education and Training Studies, 8(5). https://doi.org/10.11114/jets.v8i5.4721

Elsafty, A., Elsayed, H., \& Shaaban, I. (2020). Educating Engineering Students in Egypt: Recommendations for Improvement. International Journal of Higher Education. https://doi.org/10.5430/ijhe.v9n3p1

Elsafty, A., Elsayed, H., \& Shaaban, I. (2020). Journal of Education and Training Studies, 8(8). https://doi.org/10.11114/jets.v8i8.4901

Field, A. (2009). Disccovering Statistics Using SPSS (3rd ed.). London: SAGE.

Fitzpatrick, M., Gill, I., Ari Libarikian, Smaje, K., \& Zemmel, R. (2020). The digital-led recovery from COVID-19: Five questions for CEOs. McKinsey \& Company.

Forum, W. E. (2018). The Future of Jobs Report. Geneva: World Economic Forum.

Frey, C. B., \& Osborne, M. A. (2013). The Future of Employment. Oxford, England: Oxford Martin Programme on Technology and Employment.

Fuei, L. K. (2017). Automation, Computerisation and Future Employment in Singapore.

Gavin, R., Harrison, L., Plotkin, C. L., Spillecke, D., \& Stanley, J. (2020). The B2B digital inflection point: How sales have changed during COVID-19. Mckinsey. 
Henke, N., Puri, A., \& Saleh, T. (2020). Accelerating analytics to navigate COVID-19 and the next normal. Mckinsey.

Hite, L. M., \& McDonald, K. S. (2020). Careers after COVID-19: challenges and changes. Taylor \& Francis Online.

Kropp, P., \& Dengler, K. (2019). The Impact of Digital Transformation on Regional Labour Markets in Germany: Substitution Potentials of Occupational Tasks. In Challenges of Digital Inequality - Digital Education, Digital Work, Digital Life (pp. 1-8). Retrieved from www.ssoar.info

Mankiw, N. G. (2003). Principles of Economics. South-Western.

Pablo Illanes, Susan Lund, Mona Mourshed, Scott Rutherford, and Magnus Tyreman. (2018). Retraining and reskilling workers in the age of automation. McKinsey \& Company.

Pouliakas, K. (2018). Determinants of Automation Risk in the EU Labour Market: A Skills-Needs Approach. 11829. Bonn, Germany: IZA Institute of Labor Economics.

Spitz-Oener, A. (2006). Technical Change, Job Tasks, and Rising Educational Demands: Looking outside the Wage Structure. Journal of Labor Economics, 24(2), 235-270.

Stevenson, B. (2020, July). The Initial Impact of COVID-19 on Labor Market Outcomes Across Groups and the Potential for Permanent Scarring.

Sunders, M., Lewis, P., \& Thronthill, A. (2012). Students, Research Metods for Business (6th ed.). England: Pearson Educaion Limited.

Wilk, Shapiro, S. S., \& B, M. (1965, Dec). An Analysis of Variance Test for Normality (Complete Samples). Biometrika, 52, 591-611.

\section{Appendix 1}

\section{The Questionnaire to answer Q1}

Given that your job is consists of many tasks, one or more tasks which may be included in your job profile. If any one of the below tasks is included in your profile, please determine the appropriate percentage $(5 \%, 10 \% \ldots \ldots . .50 \% \ldots 90 \%)$ this task(s) consumed from your working hours. The total should not exceed $100 \%$ and can be in any range started from $0 \%$ to $100 \%$, inputs to be filled in table 5 .

Table 5. Required Input for Q1

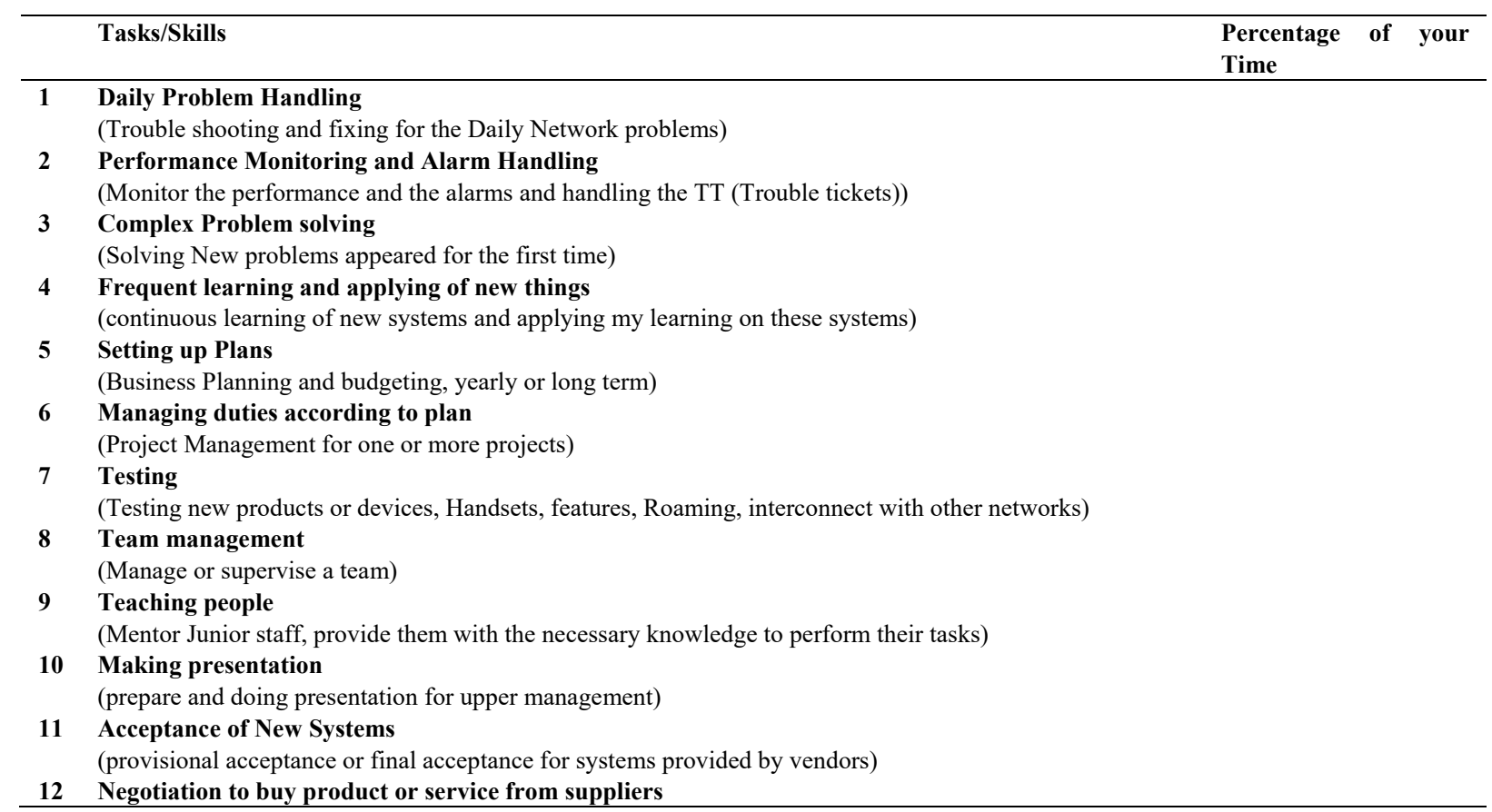




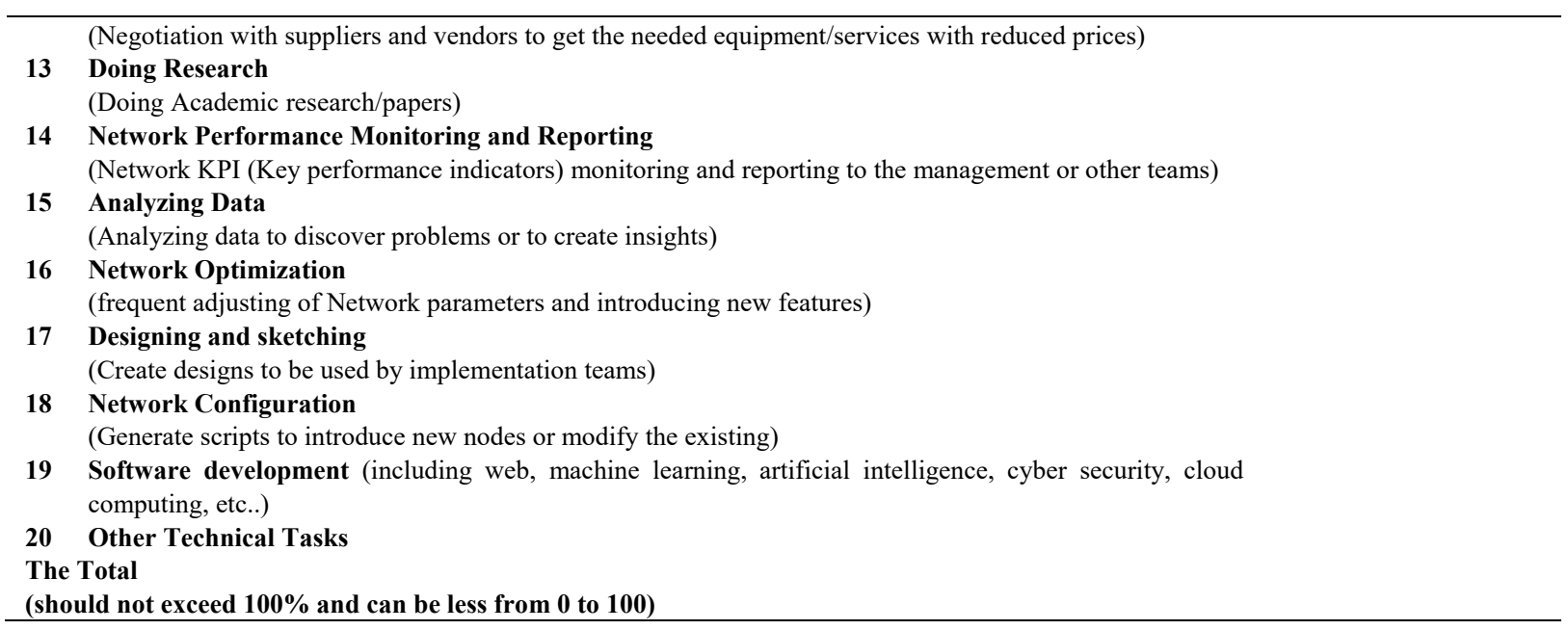

To answer Q2: We used the previous sample and ask other questions and we will statistically analyze their answers as seen in table 6 .

\section{The Questionnaire to answer Q2}

do you consider WFH was a good opportunity to increase your knowledge/skills

Table 6: Required Input for Q2

\begin{tabular}{|l|l|l|l|l|}
\hline $\begin{array}{l}\text { Strongly do not } \\
\text { agree }\end{array}$ & Do not Agree & $\begin{array}{l}\text { Neither Agree nor } \\
\text { disagree }\end{array}$ & Agree & Strongly agree \\
\hline & & & & \\
\hline
\end{tabular}

\section{Appendix-2}

To prove or reject (H10, H20):

We divided the data obtained to answer question 1 to two equal groups, high risk group in which $40 \%$ of their tasks are potential for automation, and medium/low risk group in which their automatable tasks are less than $40 \%$. The two groups will be examined statistically, using "Independent-Samples T-test", and we will use the data obtained from the following questions: to find is there a difference against the two groups in performing Reskilling and Upskilling the required input to be filled in tables 7, 8, 9, 10, 11, 12.

Did WFH help you to increase your technical knowledge/skills in fields Outside your job which will help you to change your carrier?

Table 7. Required Input for Hypotheses testing (1)

\begin{tabular}{|l|l|}
\hline Yes & No \\
\hline & \\
\hline
\end{tabular}

If yes

2 In which one of the following tasks? fill the input in table 8. 
Table 8. Required Input for Hypotheses testing (3)

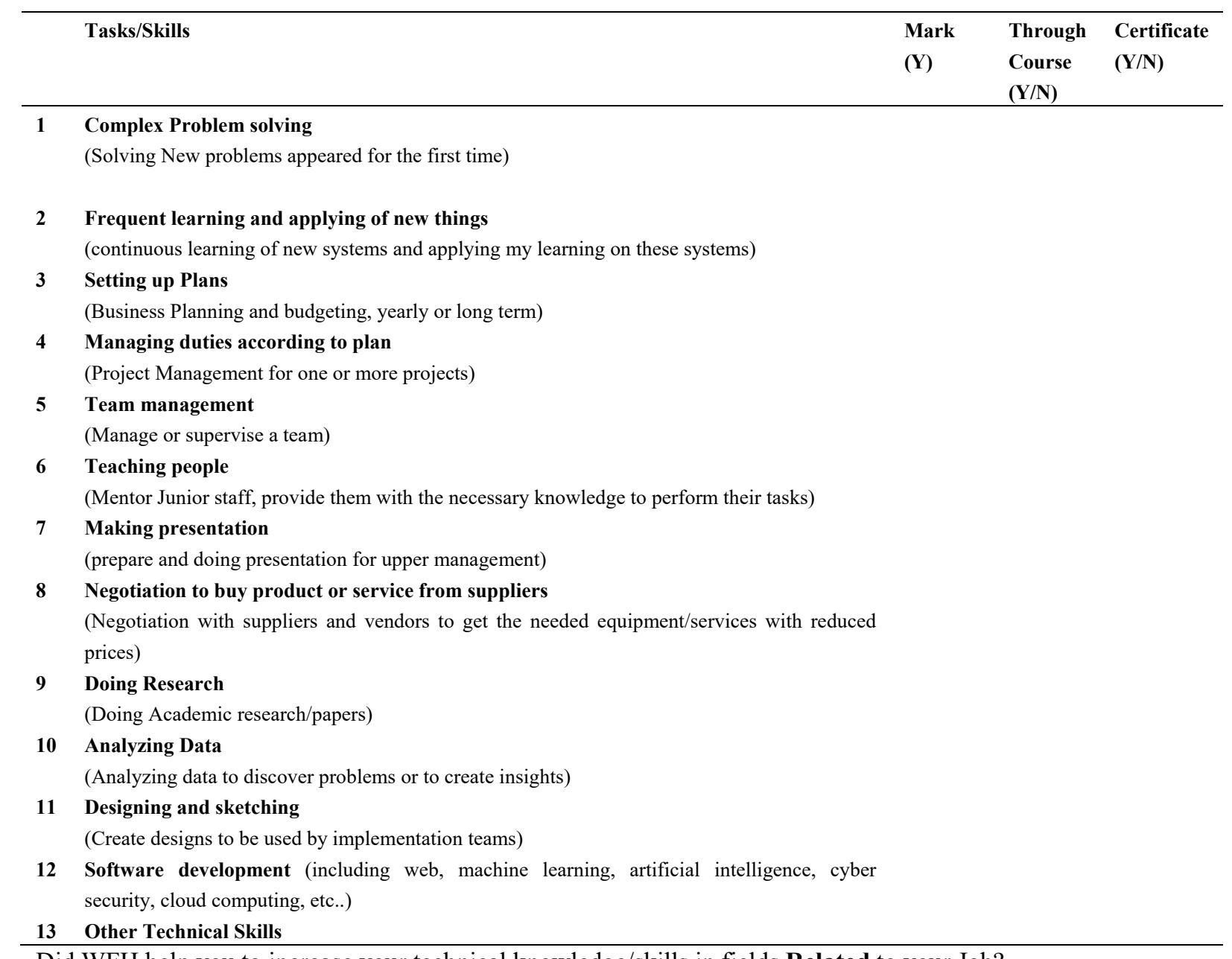

Did WFH help you to increase your technical knowledge/skills in fields Related to your Job?

Table 9. Required Input for Hypotheses testing (4)

\begin{tabular}{|l|l|}
\hline Yes & No \\
\hline & \\
\hline
\end{tabular}

4-a In which one of the following: ("Using the same table of the previous hypothesis").

\section{Appendix-3}

Q3 Questionnaires:

1- What was the newly digital introduced products?

2- How many new jobs was created? For outsiders? Or insiders?

3- What was these jobs?

4- Were these new created jobs, did include the following tasks (inputs to be filled in the same table used for answering Q1). 


\section{Appendix-4}

Q4 Questionnaires:

1- How many jobs was saved due to Automation \& AI? Can you give examples?

2- Did Automation \& AI in your area created complementary jobs for the new automated systems? How many and what are they?

3- how many insiders or outsider were assigned in the new created jobs?

4- Were these new created jobs, did include the following tasks? (inputs to be filled in the same table used for answering Q1).

\section{Copyrights}

Copyright for this article is retained by the author(s), with first publication rights granted to the journal.

This is an open-access article distributed under the terms and conditions of the Creative Commons Attribution license (http://creativecommons.org/licenses/by/4.0/). 